SUE KEDGLEY is a former Green $M P$, a columnist and author of six books.

\section{Old abortion law still holds}

\section{sway}

Fighting to choose: The abortion rights struggle in New Zealand, by Alison McCulloch, Wellington: Victoria University Press, 2013, 329 pp. ISBN 9780864738868.

IGHTING to Choose is a fasci-
nating, meticulously researched history of the struggle to liberalise New Zealand's abortion laws. It examines why there is still no right to have an abortion in a progressive country like New Zealand, which has a strong record of promoting women's rights, and why it is that an unsatisfactory abortion law, that was passed 35 years ago, is still on the statute books.

McCulloch argues that after 35 years of struggle and on-going campaigns, there is still a strong cultural taboo against having an abortion, and women's access to abortion is under constant attack from an anti-abortion lobby that, like rust, never sleeps, but keeps trying to chip away at women's

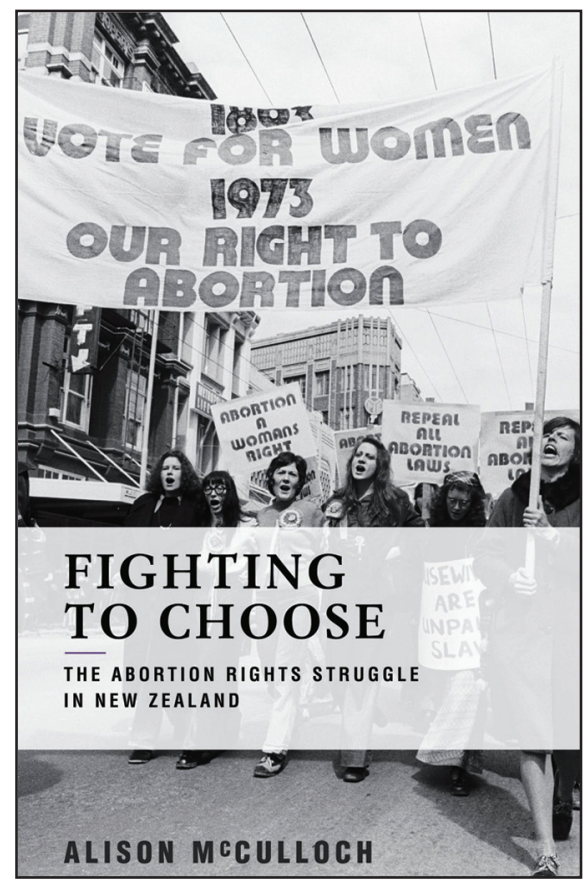

right to have an abortion.

Women's right to choose and their freedom to control their own reproductive lives was one of the key goals of the women's liberation movement, and a major focus of the movement in the 1970s. Yet while many of the goals of the women's liberation movement have been achieved, women have never won the right to choose an abortion and as a result, New Zealand women still have to prove they are mentally unstable before two physicians, to get an abortion.

McCulloch traces the early campaigns to get the law changed, the divisions within the movement over 
abortion-particularly between the uncompromising, radical stance of the Women's National Abortion Action Campaign, (Wonaac) and the more reformist and moderate agenda of the Abortion Law Reform Association, Alranz.

She details the fierce lobbying of the anti-abortion lobby, its close ties with the Catholic Church, and its incredibly effective lobbying of members of Parliament. She argues that the on-going anti-abortion campaigns are a cover for a much broader, socially conservative, anti-feminist agenda.

She variously blames religious blackmail, Parliamentary chauvinism, feminist disarray and political cowardice for the failure to liberalise our abortion laws (p. 17).

But the key obstacle facing prochoice campaigners, she argues, was their inability to find a political party to sponsor a major overhaul of New Zealand's abortion laws, and so campaigners were 'left to twist in the political winds' (p.30).

The Labour Party under Prime Minister Norman Kirk was initially openly hostile to abortion, and the Royal Commission on Contraception, Sterilisation and Abortion was set up in 1975 , partly as a way of kicking for touch and getting it off the political agenda. The Royal Commission came out with a conservative set of recommendations that were enshrined in the Contraception, Sterilisation and Abortion law that was passed in December 1977 (with only four women in Parliament) and this law has remained in force ever since.

Several attempts were made to amend the law in the 1980s, when more women had entered Parliament as a result of the women's movement, and Labour had begun to advocate for change. 'But by then it was too late for abortion rights. A bad law had been passed and the bruising battles to pass it ensured there would be little appetite for more of the same' (p. 30).

When Anne Hercus was approached to sponsor a law change, she said she was not willing to commit political suicide (p. 257). Marilyn Waring put it more diplomatically. She supported repeal of the law, but considered it politically unsafe to pursue it at the time (p. 258).

It is certainly true that politicians who have taken up the cause have all been burned in some way. Pro-repeal MP Marilyn Waring says she felt personally battered by abortion law campaigners, as did Dame Margaret Shields, who was a vocal supporter of women's right to choose.

The latest to suffer is former Labour MP and Minister Steve Chadwick, who began drawing up a private member's bill to decriminalise 
abortion in 2010. When news leaked out, the reaction from opponents, and some in her own party, was fierce and the bill was withdrawn within a month. Chadwick was subsequently demoted down the Labour list and failed to retain her seat in Parliament. 'I cannot see another MP prepared to be named to stand beside any law reform change,' she has said (p. 263).

McCulloch has no truck with those who argue that since about 1500 women have an abortion each year, women have effectively won the battle and do have a right to abortion. The law as it stands is hypocritical, demeaning to women and effectively means that the state controls women's bodies, she argues.

But the reality is that the law is unlikely to change any time soon. Few women are willing to speak out in favour of changing it, for fear of what might take its place, and there are many other women's issues competing for political attention. The pro-choice movement has shrunk to near invisibility. There is no public clamour for change, and political parties fear it would be politically suicidal to take up the cause.

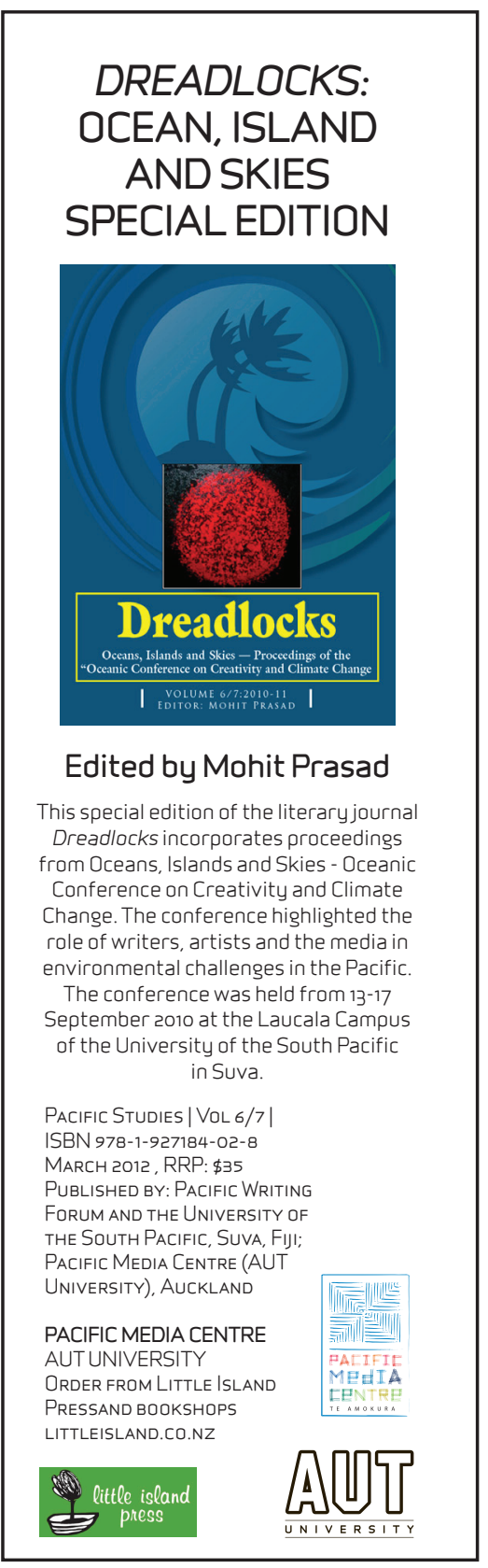

